\title{
PROBLEM SOLVING ANALYSIS OF DISTANCE PRACTICUM IN PHYSICS SUBJECTS AT MTS DDI SEPPANGE
}

\author{
Napsawati ' Fitriani Kadir \\ Physics Education Department, Universitas Muslim Maros, nafsa.wati@gmail.com
}

\begin{abstract}
Abstrak
Sejak ditetapkannya Corona Virus Disease (COVID-19) sebagai pandemi dunia oleh WHO dan ditetapkannya Negara Indonesia sebagai salah satu Negara yang terpapar oleh virus tersebut pada bulan maret 2020 menyebabkan hampir seluruh tatanan kehidupan sosial mengalami perubahann, termasuk dalam bidang pendidikan. Perubahan tersebut menyebabkan muncul berbagai masalah baru dalam pembelajaran disekolah terutama pada mata pelajaran yang berisikan praktikum. Penelitian ini bertujuan untuk menganalisis pemecahan masalah yang diterapkan di MTs DDI Seppange sehingga dapat mengatasi kesulitan yang dihadapi oleh peserta didik dalam pelaksanaan praktikum jarak jauh. Penelitian ini dilaksanakan pada sekolah MTs DDI Seppange, Bone Sulawesi Selatan dengan sampel penelitian yaitu peserta didik kelas IX MTs DDI Seppange pada tahun ajaran 2019/2020 yang berjumlah 24 orang dan 1 orang guru mata pelajaran IPA MTS DDI Seppange. Langkah penelitian meliputi: perencanaan praktikum, pelaksanaan praktikum, dan evaluasi hasil praktikum. Sedangkan metode pengumpulan data dilakukan dengan observasi, wawancara dan kuesioner. Selanjutnya data yang diperoleh dianalisis secara deskriptif kualitatif. Hasil penelitian yang diperoleh menunjukkan bahwa solusi yang diterapkan dalam penelitian ini yaitu pedoman praktikum jarak jauh dengan memanfaatkan alat dan bahan yang mudah didapatkan serta dengan metode hands on layak untuk diterapkan.
\end{abstract}

\begin{abstract}
Since the stipulation of Corona Virus Disease (COVID-19) as a world pandemic by WHO and the stipulation of the State of Indonesia as one of the countries exposed to the virus in March 2020, almost all social life arrangements have changed, including in the field of education. These changes cause new problems to emerge in school learning, especially in subjects that contain practicum. This study aims to analyze the problems that are applied at MTs DDI Sepange so that they can overcome the difficulties faced by students in implementing distance practicum. This study aims to analyze the extent to which problem solving applied at MTs DDI Seppange can overcome the difficulties faced by students in the implementation of distance practicum. To achieve this goal, this research was carried out at the MTs DDI Seppange school, Bone, South Sulawesi with the research sample being class IX students at MTs DDI Seppange in the 2019/2020 school year totaling 24 people and science subject teachers at MTS DDI Seppange. The research steps include: practicum planning, practicum implementation, and practicum result evaluation. While the method of data collection is done by observation, interviews and questionnaires. Furthermore, the data obtained were analyzed descriptively qualitatively. The results obtained indicate that the solution applied in this study is a distance practicum guide by utilizing easily available tools and materials and the hands-on method is feasible to apply.
\end{abstract}

Kata kunci: pemecahan masalah; praktikum jarak jauh.

\section{PENDAHULUAN}

Sejak ditetapkannya Corona Virus Disease (COVID-19) sebagai pandemi dunia oleh WHO dan ditetapkannya Negara Indonesia sebagai salah satu Negara yang terpapar oleh virus tersebut pada bulan maret 2020 menyebabkan hampir seluruh tatanan kehidupan sosial mengalami perubahan. Begitupun halnya dengan tatanan dunia pendidikan yang mengalami perubahan drastis sejak dikeluarkannya Surat Edaran Mendikbud Nomor 4 Tahun 2020 dan diperkuat oleh Surat Edaran Sekjen Nomor 15 Tahun 2020 tentang
Pedoman Pelaksanaan Belajar dari Rumah (BDR) selama darurat Covid-19. (Kementerian Pendidikan dan Kebudayaan, 2020).

Dengan adanya surat edaran tersebut maka pilihan yang dapat ditempuh selama adanya pandemi ini yaitu memutus mata rantai Covid 19 dengan tetap berupaya memenuhi layanan pendidikan meskipun sebagian besar dilakukan secara jarak jauh termasuk didalamnya yaitu proses pembelajaran dilakukan secara jarak jauh atau belajar dari rumah (BDR)

Pembelajaran secara jarak jauh diharapkan dapat memberikan pengalaman belajar yang 
bermakna kepada peserta didik tanpa terbebani untuk menuntaskan seluruh capaian kurikulum dengan tetap mempertimbangkan kesenjangan akses terhadap fasilitas pembelajaran jarak jauh yang berbeda-beda antara tiap peserta didik. Hal tersebut sejalan dengan yang telah diungkap oleh peneliti sebelumnya bahwa tujuan dari model pembelajaran jarak jauh saat ini adalah menyiapkan peserta didik agar dapat bersaing di era digital dengan melakukan proses pembelajaran secara rileks. (Napsawati, 2020)

Untuk memberikan pembelajaran yang bermakna, maka mata pelajaran yang berisikan praktikum tetap harus dilaksanakan meskipun secara jarak jauh. Salah satu mata pelajaran yang terdapat beberapa percobaan di dalamnya yaitu pelajaran IPA Fisika yang ada di lingkup SMP/MTs sederajat.

Hasil penelitian yang telah dilakukan oleh Napsawati (2019) mengemukakan bahwa pelajaran IPA fisika merupakan salah satu mata pelajaran yang ditakuti dan kurang digemari oleh peserta didik dengan anggapan pelajaran IPA fisika terlalu rumit untuk dipahami. Dari hasil penelitian tersebut menunjukkan bahwa untuk mengatasi kesulitan peserta didik dalam memahami materi IPA fisika dibutuhkan sebuah upaya salah satunya yaitu melakukan percobaan-percobaan yang berkaitan dengan materi yang ada agar peserta didik tersebut lebih memahaminya. Namun jika dikaitkan dengan uraian diatas, bahwa proses pembelajaran telah mengalami perubahan drastis sejak adanya pandemi mengakibatkan proses pembelajaran harus dilakukan secara daring atau jarak jauh termasuk didalamnya yaitu praktikum jarak jauh.

Namun berdasarkan hasil wawancara awal dengan guru mata pelajaran IPA Fisika menggambarkan praktikum IPA Fisika selama pelaksanaan Pembelajaran Jarak Jauh tidak dilaksanakan karena sulitnya melaksanakan praktikum tersebut secara jarak jauh. Selanjutnya berdasarkan wawancara lebih lanjut dengan guru mata pelajaran IPA Fisika mengemukakan bahwa pelaksanaan praktikum IPA Fisika selama pandemi tidak dilaksanakan karena keterbatasan ketersediaan alat dan bahan yang akan digunakan selama praktikum. Sehingga dengan demikian maka perlu adanya pedoman praktikum yang berisikan pemanfataan alat dan bahan sederhana sebagai acuan dan petunjuk dalam melakukan praktikum jarak jauh.

Secara umum praktikum adalah subsistem dari pembelajaran yang merupakan kegiatan terstruktur dan terjadwal yang memberi kesempatan kepada peserta didik untuk mendapatkan pengalaman yang nyata dalam rangka meningkatkan pemahaman peserta didik tentang teori atau agar peserta didik menguasai keterampilan tertentu yang berkaitan dengan suatu pengetahuan atau suatu mata pelajaran. (Afreni Hamidah, dkk, 2014) sedangkan menurut Suharsono (2011) praktikum adalah bagian dari pengajaran yang bertujuan agar peserta didik mendapat kesempatan untuk menguji dan melaksanakan dalam keadaan nyata apa yang didapat dalam teori.

Selanjutnya praktikum jarak jauh merupakan bagian dari model pembelajaran daring atau pembelajaran dalam jaringan. Dengan model pembelajaran daring saat ini, ada beberapa peserta didik yang menerima pembelajaran daring alasannya karena model pembelajaran daring lebih santai, menyenangkan, fleksibel, efisien, singkat, praktis, cepat, tepat, aman, mudah, hemat waktu, hemat tenaga. Cara itu juga bisa dilakukan jarak jauh tanpa berkumpul di tempat yang sama. Namun di samping kemudahan tersebut tentunya pembelajaran jarak jauh juga menimbulkan masalah baru dalam pendidikan (Napsawati 2020).

Masalah baru yang ditimbulkan dari praktikum pada pelaksanaan pembelajaran jarak jauh yaitu kurangnya kesiapan para guru dalam menghadapi perubahan yang sifatnya tiba-tiba dan drastis. Terlebih lagi bagi guru yang mengampu mata pelajaran yang memuat beberapa percobaan atau praktikum di dalamnya. Pada dasarnya praktik atau praktikum merupakan salah satu bentuk kegiatan belajar mengajar yang dimaksudkan untuk memantapkan penguasaan materi yang bersifat aplikatif Sadjati (2013). 
Tujuan dari adanya praktikum pada mata pelajaran IPA khususnya pada bagian pembahasan Fisika yaitu agar peserta didik dapat memahami secara mendalam konsep dari materi IPA Fisika tersebut. Selain itu, dengan adanya praktikum pada mata pelajaran IPA Fisika pada Sekolah Menengah Pertama bertujuan agar peserta didik dapat menemukan pemahaman baru yang berdasarkan pada teori yang telah dipelajari sebelumnya. Dengan demikian maka praktikum merupakan metode pembelajaran yang dapat menumbuh kembangkan rasa ingin tahu, inovatif, dan kreativitas peserta didik dalam menghadapi sebuah permasalahan. Secara garis besar praktikum sering dikaitkan dengan beberapa tujuan:

1. Untuk memotivasi peserta didik sebab kegiatan praktikum pada umumnya menarik bagi peserta didik sehingga mereka lebih termotivasi untuk belajar sains

2. Untuk mengajarkan keterampilan dasar ilmiah

3. Untuk meningkatkan pemahaman konsep

4. Untuk memahami dan menggunakan metode ilmiah

5. Untuk mengembangkan sikap sikap ilmiah. Berdasarkan uraian diatas menunjukkan bahwa metode praktikum adalah proses yang sangat penting (Jamaludin 2015).

Hal tersebut sejalan dengan teori yang menyatakan bahwa metode praktikum adalah sebuah metode yang harus diikuti oleh semua peserta didik agar peserta didik tersebut dapat menemukan sebab suatu masalah, membuktikan kebenaran sebuah teori dan menyimpulkannya (Zunaidah 2020).

Kelebihan lainnya dari kegiatan pelaksanaan praktikum yaitu membuat peserta didik lebih percaya atas kebenaran atau kesimpulan berdasarkan percobaan dan dapat membina peserta didik untuk membuat terobosanterobosan baru dengan penemuan dari hasil percobaannya dan bermanfaat bagi kehidupan manusia. Hasil-hasil percobaan yang berharga dapat dimanfaatkan untuk kemakmuran manusia.

Kelebihan lainnya kegiatan praktikum yaitu:
1. Mampu menumbuhkan kepercayaan peserta didik atas kebenaran atau kesimpulan melalui eksperimen yang dilakukannya dari pada sekedar menerima penjelasan dari guru atau dari buku

2. Mampu mengembangkan sikap untuk mengadakan studi eksplorasi tentang sains dan teknologi

3. Memberikan pengalaman pada peserta didik dalam belajar dengan mengalami atau mengamati sendiri suatu proses atau fenomena

4. Hasil belajar akan tersimpan lebih lama dalam diri peserta didik dan terjadi proses internalisasi. (Eliyarti \& Chichi Rahayu 2019)

Berdasarkan uraian di atas, menunjukkan bahwa praktikum sangat berperan penting dalam meningkatkan kemampuan peserta didik dalam mengorganisasi, mengkomunikasi, dan menginterpretasi hasil observasi. Sehingga praktikum merupakan salah satu bagian terpenting dalam mata pelajaran tertentu.

Praktikum yang sangat penting dalam pembelajaran di masa pandemi harus mengalami perubahan yaitu praktikum yang awalnya dilakukan secara langsung disekolah dan di bawah pengawasan guru harus dilaksanakan secara jarak jauh. Dengan diterapkannya praktikum jarak jauh maka muncullah berbagai masalah yang berkaitan dengan keberlangsungan praktikum tersebut.

Adapun permasalahan yang timbul dalam pembelajaran jarak jauh termasuk dalam hal ini praktikum jarak jauh antara lain sebagai berikut:

1. Metode pembelajaran yang kurang fleksibel karena terdapat beberapa percobaan atau praktikum mata pelajaran yang harus dilakukan secara daring atau dengan jarak jauh.

2. Praktikum yang dilakukan secara jarak jauh menyulitkan peserta didik karena keterbatasan alat dan bahan yang akan digunakan.

3. Praktikum dengan jarak jauh adalah sesuatu yang sangat sulit dilakukan oleh peserta 
didik jika dalam proses praktikum tersebut tidak ditunjang dengan pemahaman konsep yang tinggi.

4. Terdapat kemungkinan peserta didik menjadi kurang disiplin saat belajar karena tidak adanya pengawasan intens dari para guru.

5. Adanya kendala jaringan dan fasilitas. Fasilitas yang dimaksud disini adalah ketersediaan laptop atau handphone. Hal tersebut menjadi kendala karena tidak semua peserta didik memiliki fasilitas yang dibutuhkan.

Munculnya berbagai masalah yang berkaitan dengan pelaksanaan praktikum pada pembelajaran jarak jauh maka perlu adanya pemecahan masalah agar peserta didik tetap tetap dalam melaksanakan praktikum secara jarak jauh.

Pemecahan masalah dalam pandangan para psikolog aliran Gestalt pemecahan masalah dikonseptualisasikan sebagai proses pengorganisasian kognitif seseorang. (Sulasmono 2012). Sementara menurut (Saputri 2019) pemecahan masalah adalah proses yang dilakukan seseorang dalam mengkombinasi pengetahuan-pengetahuan sebelumnya untuk menyelesaikan tugas yang belum diketahui prosedur penyelesaiannya. Masih dalam Saputri (2019) Taplin mendefinisikan pemecahan masalah sebagai sebagai sekumpulan tindakan yang diambil untuk menyelesaikan tugas atau masalah. Sedangkan menurut Cahyani Setyawati (2016) Pemecahan masalah merupakan salah satu tujuan dalam proses pembelajaran ditinjau dari aspek kurikulum.

Berdasarkan uraian di atas menunjukkan bahwa praktikum merupakan suatu kegiatan yang sangat penting bagi peserta didik dalam memahami materi pelajaran khususnya mata pelajaran IPA Fisika. Sehingga penelitian ini bertujuan untuk menganalisis sejauh mana pemecahan masalah yang diterapkan di MTs DDI Seppange dapat mengatasi kesulitan yang dihadapi oleh peserta didik dalam pelaksanaan praktikum jarak jauh. Pemecahan masalah yang diterapkan yaitu pedoman praktikum yang berisikan pemanfaatan alat dan bahan sederhana, sehingga peserta didik tetap dapat melaksanakan praktikum meskipun secara jarak jauh.

dengan menerapkan pedoman praktikum yang telah dirancang sesuai dengan kebutuhan peserta didik tersebut.

\section{Metode Penelitian}

Penelitian ini menggunakan metode deskriptif kualitatif. Arikunto (2013) mengemukakan bahwa penelitian kualitatif menunjukkan bahwa pelaksanaan penelitian ini terjadi secara alamiah,apa adanya,dalam situasi normal yang tidak dimanipulasi keadaan dan kondisinya,menekankan pada deskripsi yang sewajarnya. Dengan sifatnya ini maka dituntut keterlibatan peneliti secara langsung di lapangan, tidak seperti penelitian kuantitatif yang dapat mewakilkan orang lain untuk menyebarkan atau melakukan wawancara terstruktur.

Penelitian ini dilaksanakan pada sekolah MTs DDI Seppange, Bone Sulawesi Selatan dengan sampel penelitian yaitu peserta didik kelas IX MTs DDI Seppange pada tahun ajaran 2019/2020 yang berjumlah 24 orang dan guru mata pelajaran IPA MTS DDI Seppange. Langkah penelitian meliputi: perencanaan praktikum, pelaksanaan praktikum, dan evaluasi hasil praktikum. Sedangkan metode pengumpulan data dilakukan dengan observasi, wawancara dan kuesioner dengan tingat validitas sebesar observasi dengan realibilitas sebesar 0,880 dan validitas sebesar 0,891, wawancara dengan realibilitas sebesar 0,879 dan validitas sebesar 0991 dan kuesioner sebesar 0,805 validitas sebesar 0,990. Untuk mengukur tingkat kelayakan solusi yang diterapkan berupa pedoman praktikum jarak jauh menggunakan uji Gregory dengan dua pakar sedangkan untuk mengukur tingkat kelayakan penggunaan pedoman praktikum berdasarkan tanggapan responden menggunakan kuesioner yang terdiri atas 3 indikator yaitu kemudahan memahami pedoman, kemudahan melaksanakan praktiku dan kesesuaian praktikum dengan materi. 
Selanjutnya data yang diperoleh dianalisis secara deskriptif kualitatif.

Langkah awal dalam penelitian ini yaitu perencanaan praktikum. Perencanaan praktikum dalam penelitian ini sangat penting untuk menentukan isi dan gambaran pedoman praktikum yang akan diterapkan. Perencanaan praktikum meliputi persiapan awal sebelum melakukan praktikum jarak jauh yaitu menggali informasi terkait permasalahan yang dihadapi oleh responden terkait dengan pelaksanaan praktikum selama pembelajaran jarak jauh berlangsung. Adapun informasi yang diperoleh yaitu bahwa praktikum IPA Fisika selama pelaksanaan pembelajaran jauh tidak dilaksanakan sama sekali karena sulitnya melakukan praktikum tersebut. Kesulitan itu disebabkan oleh belum tersedianya panduan atau pedoman pelaksanaan praktikum jarak jauh yang cocok diterapkan kepada peserta didik, dan tanpa pedoman praktikum tersebut sangat sulit untuk mengontrol dan mengarahkan peserta didik mengingat kondisi peserta didik yang tidak semuanya memiliki handphone.

Dari informasi tersebut, maka rancangan pedoman praktikum jarak jauh yang dirancang sesuai dengan kebutuhan peserta didik dan mengingat bahwa praktikum yang akan dilakukan secara jarak jauh maka pedoman tersebut sedikit berbeda dengan pedoman praktikum pada umumnya. Jika pada umumnya pedoman praktikum berkaitan dengan panduan praktikum dengan menggunakan alat-alat lab yang tersedia, maka dalam pedoman praktikum jarak jauh yang akan diterapkan berisikan dengan beberapa percobaan dengan memanfaatkan alat dan bahan yang mudah didapatkan dan beberapa percobaan dengan menggunakan metode hands on. Metode hands on dalam pedoman praktikum jarak jauh bertujuan agar peserta didik tidak hanya mendengarkan penjelasan guru tapi peserta didik dapat mengaitkan materi yang diterima dengan beberapa fenomena fisika dalam kehidupan sehari-hari. Hal tersebut bertujuan agar peserta didik dapat melakukan praktikum dengan rileks hal tersebut sesuai dengan tujuan dari pembelajaran jarak jauh yaitu memberikan

\section{Hasil dan Pembahasan}

pengalaman belajar yang bermakna kepada peserta dengan rileks.

Untuk memudahkan peserta didik dalam memahami pedoman tersebut maka setiap percobaan dilengkapi dengan gambar sesuai dengan langkah-langkah percobaan agar peserta didik dapat tetap memahami langkahlangkahnya meskipun tidak dalam pengawasan guru langsung. Selain itu, setiap kegiatan praktikum terdiri atas tujuan praktikum, dasar dan pendalaman materi yang berisikan tugastugas untuk memperdalam ilmu yang telah dipelajari dari praktikum. Berikut ini contoh salah satu isi pedoman praktikum yang telah dirancang:
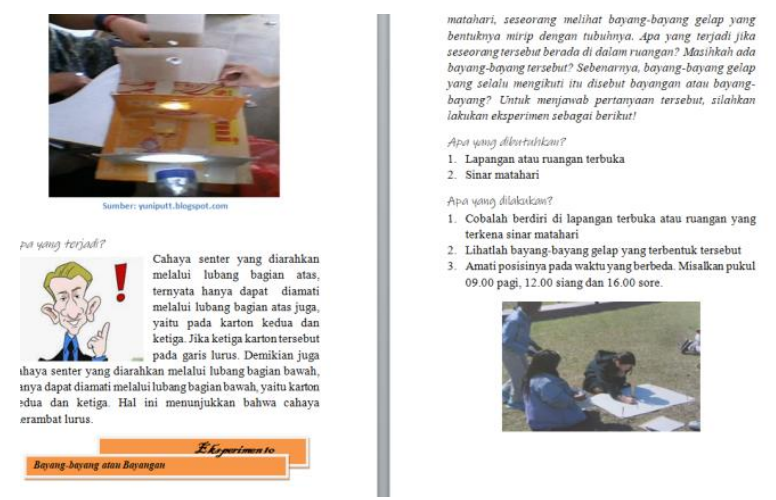

Gambar 1. Contoh isi pedoman praktikum jarak jauh

Setelah dilaksanakannya perencanaan praktikum, maka tahapan berikutnya yaitu pelaksanaan praktikum. Pada tahapan ini bertujuan untuk mengetahui apakah pedoman yang diterapkan mampu mengatasi permasalahan yang berkaitan dengan pelaksanaan praktikum selama pelaksanaan pembelajaran jarak jauh. Pada tahap pelaksanaan praktikum ini juga merupakan suatu proses kegiatan untuk merealisasikan segala sesuatu yang telah direncanakan yaitu penerapan pedoman praktikum jarak jauh selama pembelajaran jarak jauh berlangsung.

Selanjutnya, sebelum pedoman tersebut diterapkan maka dilakukan penilaian aspekaspek tertentu agar pedoman tersebut dapat dinyatakan layak untuk diterapkan. Aspekaspek yang dinilai dalam pedoman praktikum 
jarak jauh ini yaitu aspek isi, yaitu berkaitan dengan kesesuian isi pedoman dengan materi yang telah diberikan dan aspek kelayakan penyajian yang berkaitan dengan kemudahan menerapakan pedoman dalam praktikum.

Untuk menilai tingkat kelayakan tersebut maka dilakukan uji kelayakan dengan menggunakan uji Gregory. Berdasarkan penilaian yang diberikan oleh kedua pakar terhadap kelayakan pedoman praktikum IPA Fisika terkait kelayakan isi dan kelayakan penyajian pedoman sebelum diterapkan dalam praktikum diperoleh uji validitas sebesar $r=0,75$. Sehingga berdasarkan kreteria validitas menunjukkan bahwa tingkat kevalidan berada pada kategori tinggi.

Hasil tersebut di atas menunjukkan bahwa pedoman praktikum jarak jauh dari segi isi dan kelayakan penyajian pedoman, sehingga pedoman tersebut layak untuk diterapkan. Sehingga langkah selanjutnya yaitu melaksanakan praktikum dengan bantuan pedoman praktikum yang telah dirancang. Pada pelaksanaan praktikum ini, pengawasan tidak dilakukan secara langsung oleh guru mengingat praktikum tersebut dilakukan secara jarak jauh. Namun meskipun demikian pelaksanaan praktikum terbilang cukup aman karena alat dan bahan yang digunakan merupakan alat dan bahan sederhana dan beberapa percobaan hanya melalui metode hands on atau pengamatan langsung fenomena yang terjadi dimana fenomena tersebut berkaitan dengan teori IPA Fisika.

kegiatan terakhir dalam penelitian yaitu tahapan evaluasi hasil praktikum. Kegiatan ini bertujuan untuk mengetahui sejauh mana kegiatan tersebut berjalan dan bagaimana hasilnya, sehingga dari evaluasi tersebut dapat terlihat bagaimana tanggapan responden terkait pelaksanaan praktikum dengan diterapkan pedoman yang telah dirancang sebagai upaya untuk memecahkan masalah yang dihadapi selama ini.

Untuk melihat tingkat kelayakan pedoman praktikum jarak jauh yang diterapkan berdasarkan tanggapan peserta didik terlihat pada tabel di bawah ini:

Tabel 1. Tingkat kelayakan pelaksanaan praktikum jarak jauh melalui pedoman praktikum berdasarkan tanggapan peserta didik

\begin{tabular}{lc}
\hline \multicolumn{1}{c}{ Indikator } & $\begin{array}{c}\text { Tingkat } \\
\text { Kelayakan }\end{array}$ \\
\hline $\begin{array}{l}\text { Kemudahan memahami } \\
\text { pedoman praktikum }\end{array}$ & $83,33 \%$ \\
$\begin{array}{l}\text { Kemudahan pelaksanaan } \\
\text { praktikum }\end{array}$ & $83,33 \%$ \\
$\begin{array}{l}\text { Kesesuaian praktikum dengan } \\
\text { materi }\end{array}$ & $87,5 \%$ \\
Rata-rata & $84,72 \%$ \\
\hline
\end{tabular}

Berdasarkan hasil yang ada pada tabel 1 menunjukkan bahwa peserta didik merasa sangat terbantu dengan adanya pedoman tersebut. Hal tersebut terlihat dari tingginya tanggapan peserta didik mengenai tingkat kelayakan pedoman dari segi kemudahan memahami isi pedoman tersebut, kemudahan melaksanakan praktikum dan kesesuaian praktikum dengan materi yang telah dipaparkan dengan tingkat kelayakan rata-rata sebesar $84,72 \%$.

Pada tabel 1 di atas dengan tingkat kelayakan sebesar 83,33\% untuk indikator kemudahan memahami isi pedoman tersebut menunjukkan bahwa peserta didik dapat memahami isi pedoman tersebut dengan baik sehingga meskipun tanpa pengawasan secara langsung dari guru mata pelajaran, peserta didik sudah dapat melakukan persiapan untuk melaksanakan praktikum secara jarak jauh.

Selanjutnya pada indikator kemudahan melaksanakan praktikum juga mendapatkan tingkat kelayakan tinggi yaitu 83,33\%. Hal tersebut menunjukkan bahwa dengan mudahnya peserta didik memahami pedoman praktikum tersebut maka peserta didik juga akan mudah melakukan praktikum secara jarak jauh.

Selanjutnya, yaitu tahapan terakhir dalam evaluasi hasil praktikum yaitu, peserta didik memaparkan secara tertulis hasil praktikum yang telah dilakukan dengan mengisi lembar tugas yang telah disediakan. Dan pada tahap ini 
guru mata pelajaran diminta untuk mengisi kuesioner penilaian terhadap praktikum yang telah dilakukan oleh peserta didik. Adapun hasil penilaian yang dilakukan guru mata pelajaran yaitu sebagai berikut:

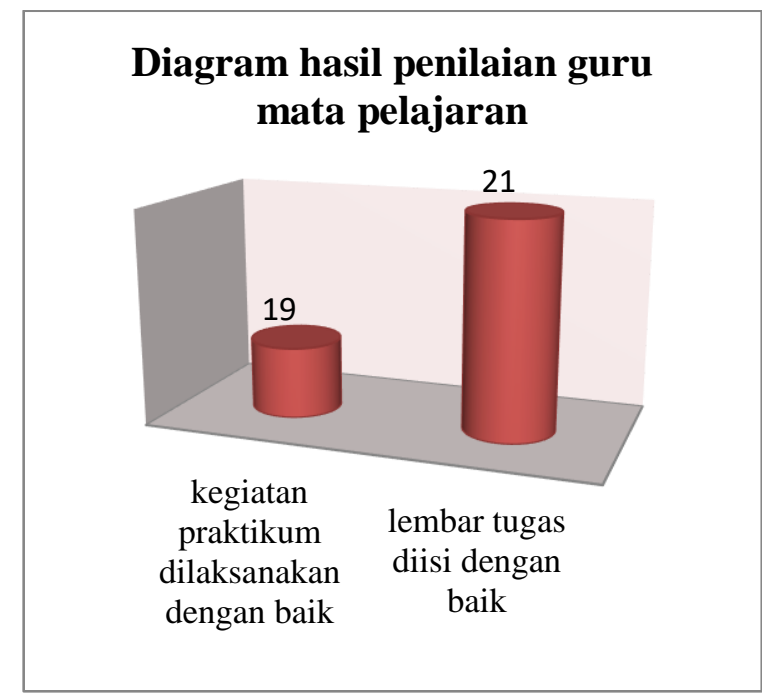

Gambar 2. Diagram hasil penilaian guru mata pelajaran terkait pelaksanaan praktikum IPA fisika secara jarak jauh

Berdasarkan diagram diatas menunjukkan bahwa dari 24 peserta didik yang dijadikan sampel penelitian, terdapat 19 peserta didik yang telah melakukan praktikum dengan baik dan terdapat 21 peserta didik yang mengisi lembar tugas dengan baik. Adanya perbedaan antara peserta didik yang mampu melaksanakan praktikum dengan baik dengan peserta didik yang mengisi lembar tugas dengan baik menunjukkan bahwa terdapat peserta didik yang tidak melaksanakan praktikum tetapi mampu menjawab lembar tugas dengan baik. Maka hal ini memberi gambaran bahwa peserta didik yang menjawab lembar tugasnya namun tidak melakukan praktikum, bisa saja mengcopy jawaban dari peserta didik lain atau mengcopy jawaban dari sumber informasi lainnya.

\section{Kesimpulan}

Berdasarkan hasil penelitian yang diperoleh menunjukkan bahwa masalah yang dihadapi oleh peserta didik MTs DDI Seppange yaitu sulitnya melaksanakan praktikum jarak jauh karena guru tidak mampu mengontrol dan mengarahkan peserta didik dalam melakukan percobaan. Sehingga dari permasalahan tersebut, maka solusi yang diterapkan dalam penelitian ini yaitu pedoman praktikum jarak jauh dengan memanfaatkan alat dan bahan yang mudah didapatkan serta dengan metode hands on atau melalui pengamatan peristiwa alam yang berkaitan dengan materi IPA Fisika. Berdasarkan uji validitas dari dua orang pakar diperoleh nilai $\mathrm{r}$ sebesar 0,75 sehingga pedoman tersebut dinyatakan layak untuk digunakan. Selanjutnya berdasarkan tanggapan peserta didik diperoleh tingkat kelayakan sebesar 87,42\%. Sedangkan berdasarkan tanggapan guru mata pelajaran menunjukkan bahwa terdapat 19 peserta didik yang telah melakukan praktikum dengan baik dan terdapat 21 peserta didik yang mengisi lembar tugas dengan baik. Sehingga saran dalam penelitian ini yaitu agar peserta guru dapat memberikan motivasi dan arahan bagi peserta didik yang kurang aktif melakukan praktikum.

\section{Daftar Pustaka}

Afreni Hamidah, dkk. (2014). Persepsi Siswa Tentang Kegiatan Praktikum Biologi Di Laboratorium SMA Negeri Se-Kota Jambi. Jurnal Sainmatika , 8(1) 49-59. https://media.neliti.com/media/publicati ons/221111-persepsi-siswa-tentangkegiatan-praktiku.pdf

Arikunto, S. (2013). Prosedur Penelitian Suatu Pendekatan Praktik. Edisi Revisi. Jakarta: PT. Rineka Cipta

Cahyani \& Ririn Wahyu Setyawati. (2016). Pentingnya Peningkatan Kemampuan Pemecahan Masalah melalui PBL untuk Mempersiapkan Generasi Unggul Menghadapi MEA. Seminar Nasional Matematika $X$ Universitas Negeri Semarang , 151-160. https://journal.unnes.ac.id/sju/index.php /prisma/article/view/21635

Eliyarti \& Chichi Rahayu. (2019). Deskripsi Efektivitas Kegiatan Praktikum Dalam Perkuliahan Kimia Dasar Mahasiswa Teknik. Jurnal Pendidikan Sains \& 
Matematika, $\quad 7(2) \quad$ 51-60. https://ejournal.undiksha.ac.id/index.ph $\mathrm{p} / \mathrm{JPK} /$ article/view/19480,

Jamaludin,dkk. (2015). Analisis Pelaksanaan Praktikum Menggunakan KIT IPA Fisika Di SMP Se-Kecamatan Sojol Kabupaten Donggala. Jurnal Pendidikan Fisika Tadulako (JPFT), 3 (1) https://core.ac.uk/download/pdf/291816 015.pdf

Kementerian Pendidikan dan Kebudayaan. (2020). SURAT EDARAN NOMOR 15 TAHUN 2O2O Tentang Pedoman Penyelenggaraan Belajar Dari Rumah Dalam Masa Darurat Penyebaran Corona Yirus D/Sease (Covid-19)

Lilis Kurniawati, dkk. (2015). Pengaruh Penerapan Metode Pembelajaran Praktikum Terhadap Keterampilan Berpikir Kritis Matematika Siswa kelas VIII SMPN 3 Sumber Kabupaten Cirebon. EduMa, 4 (2) 62-74. https://syekhnurjati.ac.id/jurnal/index.ph p/eduma/article/view/30

Moleong, Lexy J. (2015) .Metode Penelitian Kualitatif.Bandung:Remaja Rosdakarya

Napsawati. (2019). Hubungan Kinerja Dan Kepribadian Guru Dengan Motivasi Belajar Fisika Peserta Didik SMA Negeri Se Kabupaten Bantaeng. Karst, 2 (2) 64-70. https://journal.unismuh.ac.id/index.php/j pf/article/view/4074

Napsawati. (2020). Analisis Situasi Pembelajaran IPA Fisika dengan Metode Daring di Tengah wabah COVID-19. Jurnal Karst : Jurnal Pendidikan Fisika dan Terapannya, 3 (1) https://ejournals.umma.ac.id/index.php/ karts/article/view/546/447

Sadjati, Ida Melati. (2013). Persepsi Mahasiswa Tentang Penyelenggaraan Praktikum Pada Pendidikan Tinggi Terbuka Jarak Jauh (Kasus: Program Studi Agribisnis Fmipa Universitas Terbuka). Jurnal
Pendidikan Terbuka dan Jarak Jauh, 14 (1).

Saputri, R. A. (2019). Analisis Pemecahan Masalah Soal Cerita Materi Perbandingan Ditinjau dari Aspek Merencanakan Polya. Wacana Akademika: Majalah Ilmiah Kependidikan 21-38. http://download.garuda.ristekdikti.go.id/ article.php?article $=987335 \& \mathrm{val}=10892$ $\&$ title $=$ Analisis $\% 20 \mathrm{Pemecahan} \% 20 \mathrm{Mas}$ alah\%20Soal\%20Cerita\%20Materi\%20 Perbandingan\%20Ditinjau\%20dari\%20 Aspek\%20Merencanakan\%20Polya

Sulasmono, B. S. (2012). Problem Solving: Signifikansi, Pengertian, Dan Ragamny. Satya Widya , 155-166. https://core.ac.uk/download/pdf/234028 813.pdf

Suharsono. (2011). Kamus Besar Bahasa Indonesia. Semarang: Widya Karya.

Zunaidah, Farida Nurlaila. (2020). Implementasi Perkuliahan Daring Matakuliah Pendidikan Laboratorium IPA Pada Masa Pandemi. Jurnal Pendidikan Dasar Nusantara 6 (1). https://ojs.unpkediri.ac.id/index.php/pgs d/article/view/14466/1633 